\title{
Fungicidal Effect of Some Promising Agents in Controlling Maize Late Wilt Disease and their Potentials in Developing Yield Productivity
}

\author{
S. M. El-Moghazy, ${ }^{1}$, M. E. Shalaby ${ }^{2 *}$, Ahlam A. Mehesen ${ }^{3}$ and M. H. Elbagory ${ }^{3}$ \\ ${ }^{1}$ Plant Pathology Research Inst., Agric. Res. Center, ${ }^{2}$ Agric. Bot. Dept., Agric. \\ Microbiology, Faculty Agric., Kafrelsheikh Uni., Agric. Microbiol. Dept., Soil, Water \\ and Environ. Res. Inst., Agric. Res. Center, Egypt.
}

\begin{abstract}
A NIFUNGAL activities of cyanobacterial filtrate, compost tea, $\mathrm{H}_{2} \mathrm{O}_{2}$, garlic oil, A barnyardgrass root exudates and Premis fungicide were tested against Cephalosporium maydis, the pathogenic fungus of late wilt disease of maize plants. In vitro and two field trials were carried out during 2015 and 2016 growing seasons under disease nursery conditions. In vitro, cyanobacterial filtrate and $30 \%$ premis fungicide were the superior treatments, by them linear growth of $C$. maydis were prevented totally and fulfillment inhibitions (100\%) were resultedwith lowest $\mathrm{IC}_{50}$ values. Cyanobacterial filtrate and $3 \% \mathrm{H}_{2} \mathrm{O}_{2}$ were more effective in developing grain germination. Disease incidence showed better efficacy due to use $30 \%$ Premis fungicide followed by $3 \% \mathrm{H}_{2} \mathrm{O}_{2}$ with massive disease reductions reached 83.21 and $75.37 \%$, respectively during 2015 season. Effectiveness of the $3 \% \mathrm{H}_{2} \mathrm{O}_{2}$ dose was extended to the 2016 season with $5.11 \%$ disease incidence and $73.39 \%$ disease reduction. For grain productivity, remarkable enhancements in the weights of both 10 ears and 1000 grains due to all treatments compared to control were recorded in both seasons. Due to their antifungal activities, qualitative analysis of Cyanobacterial filtrate and barnyardgrass root exudates was assayed on Gas chromatography mass-spectrum (GC-MS). Malonic acid, 2,3-Butandiol, Hexestrol, 12-Crown-4-ether and cis-Vaccenic acid were the major compounds extracted from the cultured blue-green algae. Whereas, Nadolol, Quinine, $\alpha$ - Methylionol, Phyllocladene, alcohols, acids, phenols and 2,6-dihydroxy benzoic acid were the most abundant antimicrobial agents in the barnyardgrass root exudates.
\end{abstract}

Keywords: Maize late wilt, Cyanobacteria, Compost tea, $\mathrm{H}_{2} \mathrm{O}_{2}$, Premis, Garlic oil, Cephalosporium maydis, Disease reduction, Productivity, Biochemical assay.

\section{Introduction}

Cephalosporium maydis is a soil-borne vascular wilt pathogen that penetrates root tissue and colonizes the xylem causes late wilt disease of maize plants. It can be transmitted through the seeds as seed-borne and may occasionally cause seed rot or pre-emergence damping-off under heavy inoculum potential (El-Shafey and Claflin, 1999). Nowadays, a great attention has been focused on the possibility for using natural and safely agents to overcome the harmful effects of the plant pathogens and in the same time to promote growth of these plants. Utilization of these agents became positive alternative to chemical pesticides and safely used for human, animal and environment (Whipps, 2001). In the last few decades, several possible plantmicrobe interactions were developed to benefit plants and colonize their roots and enhance their growth through wide variety of mechanisms, such as the production of plant growth regulators (phytohormones), antifungal activities, siderophores, phosphate solubilization, nutrient uptake and availability (Bowen and Rovira, 1999).

Compost or its extracts are the most promising bioproducts recently responsible for developing different management programs as plant pest, disease and fertility (Sheurell and Mahafee, 2002). Decomposition processes of compost are actually enhanced via inoculation with beneficial microorganisms acted, themselves or their metabolites, as plant growthpromoting rhizobacteria (PGPR) (Brinton, 1995). Compost tea was also has a great potential for controlling different diseases in addition to improvement growth of the plants (Ghobrialet al. 2009). 
Weeds are one the main suppressive factor in maize (Zea maize L.) production and cause yield losses in the cultivation system (Zoschke, 1990). Barnyardgrass (Echinochloa crus-galli) belongs to the same family of maize (Gramineae), which may be one of the reasons for its superior ability to compete with maize or rice plants. Furthermore this noxious weed may release growth inhibitors that inhibit the emergence of maize, rice and other growth parameters (Li et al., 1992; Xuan et al., 2006). Some weeds contain and release phytotoxic compounds (allelochemicals) into the environment that inhibit the growth of crops (Tang et al., 1981). Allelopathy was defined as any process involving secondary metabolites produced by plant, algae, bacteria, and fungi that influence the growth and development of agriculture and biological system (IAS, 1993) or sometimes the substances which originated from plant could play as a crop protection role.

Cyanobacteria are photosynthetic cosmopolitan prokaryotic organisms that have been isolated from aquatic (freshwater, brackish and marine), terrestrial (soil, lichen-associated and the surface of leaves), and different aquatic and terrestrial extreme environments (hot springs, high salinity, deserts) (Whitton and Potts, 2000; Kaasalann et al., 2012). In these environments, cyanobacteria face competitors and predators, including parasitic fungi, such as chytrids. The production of oligopeptides by Planktothrix spp. is believed to contribute to the defense against chytrid fungi (SØnstebØ and Rohrlack, 2011; Rohrlack et al., 2013). In cyanobacteria, the antifungal hassallidin is synthesized by NRPSs and tailoring enzymes (Vestola et al., 2014). Interestingly, a single hassallidin gene cluster encoded in the biosynthetic pathway for more than 40 chemical variants of hassallidin in Anabaena sp. SYKE748A (Vestola et al., 2014).

The objective of this study is to investigate the fungicidal and biochemical activities of certain agents for induce resistance and controlling late wilt disease on maize plants. Enhancement of plant growth and nutritive values of maize productivity were also aimed in the presented study.

\section{Materials and Methods}

\section{Pathogen}

A virulent isolate of late wilt disease pathogen was isolated from naturally infected maize (Zea mays, the susceptible "Baladi" variety) in Kafr El-

Env. Biodiv. Soil Security Vol.1 (2017)
Sheikh governorate and used through this study. The pathogen was isolated and cultured on potato dextrose agar (PDA) medium supplemented with yeast extract according to the methods described by Shalabyet al. (2009). Cultures were incubated at $28^{\circ} \mathrm{C} \pm 2 \mathrm{C}^{\circ}$ for 3-7 days and then purified by the hyphal tip technique according to Booth (1977). Pure cultures were examined microscopically and maintained on PDA slants supplemented with $0.1 \%$ yeast extract at $4{ }^{\circ} \mathrm{C}$ for further experiments. The obtained fungal isolates were identified as Cephalosporiummaydis by morphological characteristics and microscopic examination according to (Samraet al., 1962) and confirmed by comparing these isolates with the culture collection of maize, sugar and foliage crops Res. Dis. Dept., Plant Path. Res. Inst., Agric. Res. Center, Giza, Egypt.

\section{Sterilization of treatments}

Except Premis fungicide and Hydrogen peroxide, the tested treatments were sterilized by exposure to the vapor of chloroform by putting every 3 small bottles $(20 \mathrm{ml}$ in size) on conical flask $(250 \mathrm{ml})$ containing $25 \mathrm{ml}$ of chloroform, then closed with parafilm for 5 days to kill all cells of any contaminated microorganisms according to the technique ofVidaveret al. (1972) and was adapted by El Bakery (2010).

\section{Treatments}

\section{Compost tea}

For compost tea, rice straw was watered and firstly inoculated with Trichodermaviridi and $T$. harzianum. After that, the liquid cultures of the plant growth promoting rhizobacteria (PGRP) of Azotobacterchroococcum, zosperillumbrasilense and Paenibacilluspolymexa was added according to Badawi (2003). After maturation, enriched compost was filtered to obtain its extract. As foliar spraying, compost tea was diluted, five times using distilled water, and regular applied every 15 days during the vegetative stage. At the flowering stage, foliar spraying was stopped to avoid falling of the flowers. After that, further spraying was done. Chemical and biological properties of the supplemented compost tea are presented in Table (1). One kilogram of the maturated compost was immersed in $10 \mathrm{~L}$ water to obtain tea compost. Crude concentration of compost tea was diluted into $10 \mathrm{~g} \mathrm{~L} \mathrm{~L}^{-1}$ before application based on Ghobrialet al. (2009). 
TABLE 1. Chemical and biological characters of the supplemented compost tea.

\begin{tabular}{|lc|}
\hline Character & Value \\
\hline $\mathrm{pH}$ & 8.20 \\
$\mathrm{EC}\left(\mathrm{ds} \mathrm{m}^{-1}\right.$ at $\left.25^{\circ} \mathrm{C}\right)$ & 3.51 \\
$\mathrm{C} / \mathrm{N}$ ratio & 14.05 \\
Total Nitrogen $(\mathrm{ppm})$ & 148.5 \\
Total Phosphorus $(\%)$ & 0.11 \\
Total soluble Nitrogen (ppm) & 103.7 \\
Available Phosphorus $(\mathrm{ppm})$ & 19.80 \\
Cross seed germination teast $(\%)^{*}$ & 91.20 \\
Total count of bacteria $(\mathrm{cfu} / \mathrm{ml})$ & $8.7 \times 10^{7}$ \\
Total count of fungi $(\mathrm{cfu} / \mathrm{ml})$ & $1.3 \times 10^{6}$ \\
Total count of Actinomycetes $(\mathrm{cfu} / \mathrm{ml})$ & $1.2 \times 10^{6}$ \\
& \\
Cross germination test was carried out using Erucasativum \\
seeds after $72 \mathrm{hr}$.
\end{tabular}

\section{Cyanobacteria}

Mixed strains of Cyanobacteria known as Anabaena oryzae, Nostocmuscorum and $N$. calcicolawere kindly obtained from the stock culture collection of Biological Nitrogen Fixation Unit, Sakha Agric. Res. Station, Kafr El-Sheikh, Egypt. Nitrogen-fixing Cyanobacteria have been cultured routinely in a modified Allen's BG-11 free-nitrogen medium (Allen and Stainer, 1968). For the growth in the dark, $1 \%$ glucose was added to the medium. Flasks containing Allen's medium ( $\mathrm{pH} 7$ ) were inoculated with $20 \mathrm{ml}$ of homogenized combined culture of the three tested Cyanobacteria strains to get $500 \mathrm{ml}$ total volume. Cultures were incubated at $35^{\circ} \mathrm{C}$ for 20 days and illuminated on a 16 / 8 h light / dark cycle using fluorescent tubes with a light intensity of 3500 to 4500 Lux at the surface of the vessels (Abdel-Raouf and El-Shafey, 2009) Cultures were manually stirred twice for a few minutes daily. After that, number of cells was counted and adjusted at $10^{8}$ cell ml-1 using Haemocytometer. Cultures were used to impregnate sterilized soil $\left(121^{\circ} \mathrm{C}\right.$ for $30 \mathrm{~min}$.) at the rate of $52 \mathrm{ml}$ liquid culture per100 $\mathrm{g}$ soil. Inoculated soil was well mixed and maintained at room temperature for $48 \mathrm{~h}$. To store Cyanobacteria, the mixed culture was inoculated into nutrient agar medium and incubated in dark for 3 days to activate its growth before maintaining at $4{ }^{\circ} \mathrm{C}$ in the refrigerator. Cultures were filtered using cloth sheets directly before application without dilution either individual treatment or in combination with the $10 \%$ compost tea treatment.

\section{Hydrogen peroxide}

Antifungal effects of three concentrations (1, 2 , and $3 \%$ ) of the well-known induce resistance agent $\mathrm{H}_{2} \mathrm{O}_{2}(30 \%)$ were also investigated. The required concentrations were obtained by adding appropriate amount of the row dose (1,2 and $3 \mathrm{ml})$ to complete $100 \mathrm{ml}$ portions of autoclaved PDA medium cooled to about $45^{\circ} \mathrm{C}$. A non-amended PDA medium was acted as control.

\section{Garlic oil}

Garlic oil (produced by CAP-Pharm, Reg. No. $2849 / 2002$ ) was purchased from local market. The required concentrations $(1.5,3$ and $6 \%$ ) were obtained by adding appropriate amount of the row plant oils (1.5, 3 and $6 \mathrm{ml})$ to complete $100 \mathrm{ml}$ portions of autoclaved PDA medium cooled to about $45^{\circ} \mathrm{C} . \mathrm{A}$ non-amended PDA medium was acted as control.

\section{Barnyardgrass root exudates}

Barnyardgrass (Echinochloa crus-galli) is a well-known weed plant commonly naturally grows during summer cultivations of field crops. The grains of Barnyardgrass were grown in jars containing Cooper nutritious solution (Cooper, 1973) and glass granules under room conditions. After their growth, Barnyardgrasswas filtered using filter paper Whatman No.1.then sterilized it.

\section{Chemical fungicide}

Chemical fungicide known asPremis was tested against the investigated pathogenic isolate. Trade and common name, chemical and molecular formula and recommended dose of the tested chemical fungicide premis in Table (2) were done. Successive concentrations represented as 10, 20 and $30 \%$ were tested. To set these concentrations, a stock solution of $10 \mathrm{~g} \mathrm{~L}^{-1}$ was first prepared using sterilized distilled water. Then, 10, 20 and $30 \mathrm{ml}$ of the stock solution were added to flasks containing still melted sterilized PDA medium to complete their volumes up to $100 \mathrm{ml}$, respectively using membrane filter syringe of $0.2 \mu \mathrm{m}$.

After thorough handling shaking, medium was poured in $9 \mathrm{~cm}$ in diameter Petri-dishes. As replicates, three dishes of each treatment were inoculated centrally with $5 \mathrm{~mm}$ agar discs bearing mycelium of 7-days old cultures of the pathogen, then incubated at $28 \pm 2^{\circ} \mathrm{C}$. Petri-dishes free from fungicides were acted as check (control) treatment. Growth was daily observed and the maximum linear growth was measured at the time of full growth in the control treatment. Net growth data of each concentration were calculated and percentages of inhibition (I \%) was calculated by the same equation mentioned above by Ferreira et al. (1991).

To describe the relationship between

Env. Biodiv. Soil Security Vol.1 (2017) 
TABLE 2. Trade and common name, chemical and molecular formula and recommended dose of the tested chemical fungicide premis.

Trade name

Common name

Premis
Triticonazole

\section{Molecular formula \&} weight

$\mathrm{C}_{17} \mathrm{H}_{20} \mathrm{Cl} \mathrm{N} \mathrm{N}_{3} \mathrm{O}$

$(317.81)$

\author{
Chemical formula
}

(RS)-(E)-5-(4-Chlorobenzylidene)2,2-dimethyl-1-(1H-1,2,4-triazol-1ylmethyl) Cyclopentanol inhibition percentage (I \%) and concentration of the $\mathrm{H}_{2} \mathrm{O}_{2}$, garlic oil and the fungicide premis as mathematical basis, derived equation from the well-known Michaelis-Menten kinetics was applied as follows:

$$
\mu=\mu_{\max } * \mathrm{C}_{\mathrm{S}} /\left(\mathrm{K}_{\mathrm{S}}+\mathrm{C}_{\mathrm{S}}\right)
$$

where: $\mu=$ Specific growth rate $\mu_{\max }=$ Maximum specific growth rate.

$\mathrm{C}_{\mathrm{S}}=$ Concentration of the substrate.

$\mathrm{K}_{\mathrm{S}}=$ Constant affinity.

It was well applied by Shalabyet al. (2015) after modification into:

$$
\mathrm{I} \%=\mathrm{I} \%_{\max } * \mathrm{C}_{\mathrm{S}} /\left(\mathrm{K}_{\mathrm{S}}+\mathrm{C}_{\mathrm{S}}\right)
$$

where: I $\%=$ inhibition percentage

$\mathrm{I} \%_{\text {max }}=$ maximum inhibition percentage.

$\mathrm{C}_{\mathrm{S}}=$ Concentration of the tested control agents.

$\mathrm{K}_{\mathrm{S}}=$ Constant affinity of the control agents.

In which, $\mu$ and $\mu_{\max }$ were replaced by I $\%$ and I $\%$ $\max _{\text {ax }}$ respectively.

For this purpose, the linear and nonlinear least squares fitting routine of MicroCal's ORIGIN ${ }^{\circledR}$ software package was used and regression degree $\left(\mathrm{R}^{2}\right)$ of each fungicide was achieved. Based on the regression data and their slope values, concentration of each antagonist caused inhibition of $50 \%$ of the fungal growth $\left(\mathrm{IC}_{50}\right)$ could be plotted.

Antagonistic effects of the tested treatments under laboratory conditions

To test their antagonistic effects against $C$. maydis, certain concentration of each treatment was added to flask containing certain part of autoclaved PDA medium (supplemented with $0.1 \%$ yeast extract) cooled to about $45^{\circ} \mathrm{C}$ by using membrane filter syringe $0.2 \mu \mathrm{m}$. After thorough handling shaking, medium was poured in $9 \mathrm{~cm}$ in diameter Petri-dishes (15ml/dish). After solidification, Petri-dishes were inoculated centrally with $5 \mathrm{~mm}$ discs of 3 days-old cultures of $C$. maydis, and then incubated at $28-30^{\circ} \mathrm{C}$. These trials were represented by three replicates. The non-amended Petri-dishes of compost tea were acted as check control. Linear growth was daily observed and measured till a time of full growth in the control treatment. However, percentage of inhibition (I \%) was calculated for each concentration of all tested treatments in this study according to identical formula of Ferreira et al. (1991)as follows:

$$
\mathrm{I} \%=[(\mathrm{A}-\mathrm{B}) / \mathrm{A}] \times 100
$$

where:-

I $\%=$ Percentage of inhibition.

$\mathrm{A}=$ Mean diameter growth in the control.

$\mathrm{B}=$ Mean diameter growth in a given treatment.

\section{Seed germination test}

Maize grains were surface sterilized by soaking into liquid solution of sodium hypochlorite $(0.5 \%)$ for $3 \mathrm{~min}$., rinsed 3 times with distilled sterilized water before planting. Maize grains were immersed in each tested treatment for 12 hours. Grains were allowed to dry in a laminar flow cabinet for 1-2 $\mathrm{h}$ before sowing. Grains soaked in water were served as controls. Four grains were sown at a suitable depth into polyethylene boxes filled with clay-sand soils watered when needed. Each treatment was represented by three replicates. The boxes were incubated for 10 days at room temperature. Then, germination indexes and percentage of germination were calculatedestimated. Germination index was calculated according to the formula of WalkerSimmons and Sesing, (1990). Number of seeds that germinated was counted daily for ten days. Germination was defined as pericarp rupture over the embryo. A weighted germination index was calculated first and less weight to these those germinated subsequently: 


$$
\text { Germination index }=\frac{(10 \times \mathrm{n} 1+9 \times \mathrm{n} 2+\ldots . .+1 \times \mathrm{n} 10)}{(\text { Total days } \times \text { Total seeds })}
$$

where, $\mathrm{n} 1 \ldots . . \mathrm{n} 10$ are the number of seeds that germinated on the first, second and subsequently days until the $10^{\text {th }}$ days, respectively.. 10, 9, 8 are that wt. given to the No. of seeds germinated on the first, second and respectively. The maximum germination index is 1 and the minimum is 0 .

\section{Disease assessment under disease nursery field conditions}

Field trials were carried out during 2015 and 2016 seasons. Maize grains immersed for overnight in certain concentrations of the tested treatments were sowed in plots of $9.6 \mathrm{~m}^{2}$ in area containing two rows each with $6 \mathrm{~m}$. long and $80 \mathrm{~cm}$. apart and watered under disease nursery field conditions (El-Shafeyet al., 1988). Grains soaked in sterilized distilled water were served as control. Fifty grains were planted for each row in the disease nursery. Three replicates were used in these experiments. Degrees of disease assessment were recorded as percentages of disease incidence; percentages of survival plants and disease reduction were also recorded. Plants were thinned to one plant per hill 45 days from sowing and $25 \mathrm{~cm}$ between hills. Degrees of disease incidences of the survival plants were recorded, as percentage of infected plants, 35 days after silking (95 days after planting) (El-Shafey, et al., 1988) as follow:

$$
\text { Disease incidence }(D I \%)=\frac{\text { No. of infected plants }}{\text { No. of total plants }} \times 100
$$

Disease incidence data were reused to calculate percentages of disease reduction (Efficiency) of each treatment based on this formula:

$$
\text { Disease reduction } \%=\frac{D[\% \text { of control }-D] \% \text { of treatment }}{D I \% \text { of control }} \times 100
$$

On the other hand, weights of 10 ears and the 1000 grains yielded from plants of each treatment were determined.

\section{Biochemical tests}

Analysis of blue-green algae and root exudates of Echinochloagrus-galli (Barnyard grass) on GC/MS (Agilent 7000 Triple Qvad) located at
Regional center for food and feed, ARC, Giza, Egypt was done. Prior to GC-MS analysis, each sample was dissolved in toluene. GC-MS wsa performed in a fused-silica capillary column (BP5; $0.25 \mu \mathrm{m}, 30 \mathrm{~m} \times 0.25 \mu \mathrm{mm}$; SGE Ltd, Agilent 7000 Triple Qvad) using a temperature gradient $\left(120^{\circ} \mathrm{C}\right.$ for $5 \mathrm{~min}, 100$ to $160{ }^{\circ} \mathrm{C}$ at $2{ }^{\circ} \mathrm{C}$ $\left.\mathrm{min}^{-1}\right)$. The GC injector was kept at $280{ }^{\circ} \mathrm{C}$, and the GC-MS interface was kept at $250^{\circ} \mathrm{C}$. Samples (one $\mu 1$ each) were injected in split mode (1: 50) and helium $\left(1 \mathrm{ml} \mathrm{min}^{-1}\right)$ was used as the carrier gas (Abhayet al., 2007).

\section{Statistical analysis}

Data were subjected to statistical analysis of variance (ANOVA) test. A complete randomize design was applied and Duncan's multiple range tests were used for comparing means (Gomez and Gomez, 1984).

\section{Results and Discussion}

\section{Laboratory antagonism}

Inhibitory effects of the tested control agents on the linear growth of the pathogenic fungus of maize late wilt disease under laboratory conditions were done and data were tabulated in Table (3).It illustrates that the algal filtrate and $30 \%$ of premis fungicide were the superior treatments, by them linear growth of $C$. maydis were prevented totally and fulfillment inhibitions $(100 \%)$ were resulted. As well as, great inhibitory effects against the pathogenic fungus due to use 6 $\%$ of garlic oil and barnyard grass extract of 98.35 and $97.25 \%$, respectively, followed by $3 \% \mathrm{H}_{2} \mathrm{O}_{2}$ $(89.56 \%)$ were obtained compared with control. The reminder agents were varied in their effects and considered less magnitudes compared to the previous. Superiority data of the cyanobacterial extracts were in full agreement with the findings of Abed et al. (2009), who indicated that the antifungal compounds detected in cyanobacterial extracts, such as fischerellin A, hapalindole, hassallidin/balticidins, carazostatin, phytoalexin, tolytoxin, scytophycin, toyocamycin, tjipanazole, nostocyclamide, nostodione and nostofungicidine have great efficiencies against most pathogenic fungi. On the other hand, premis has a great potential, as all chemical fungicides, against hyphal cells. Potential impacts of such fungicides against the fungal cells via their ultrastructure were investigated by Abd El-Ghany and Tayel (2009). Disorder and striking changes in the cell wall of hyphae, phialides and conidiophores were 
observed on Fusariumsolani, Rhizoctoniasolani and Penicilliumcitrinum. These alterations in the wall were not detected with the untreated hyphae. Disorganization of the cytoplasm was also recorded. Additionally, vacuoles were completely disappeared under influence of the fungicides. For compost tea, presented results were less magnitudes in reducing growth mycelium of the pathogen for $23.63 \%$ instead of $31.58 \%$ by Shalaby et al. (2011).

To investigate if the inhibitory effects of $C$. maydis due to the tested agents will be extended by increasing their doses, experimental data were fitted. The fitted functions of each tested agent with the experimental data of mycelium inhibition were plotted in Fig. (1) $\mathrm{H}_{2} \mathrm{O}_{2}$, Fig. (2)Premis and Fig. (3) for garlic oil. As well as, concentration of each agent caused $50 \%$ growth inhibition $\left(\mathrm{IC}_{50}\right)$ of the pathogen was therefore determined. For this purpose, nonlinear least squares fitting routine of MicroCal's ORIGIN ${ }^{\circledR}$ software package was used. Due to their kinetic functions,Michaelis-Menten enzyme relations (Monod, 1949) were applied and found to be the least deviation curve giving the most fitting acceptable model for $\mathrm{H}_{2} \mathrm{O}_{2}$ and Premis.

It is worthy to note that the resulted $\mathrm{IC}_{50}$ values were reached to $0.7 \%$ of $\mathrm{H}_{2} \mathrm{O}_{2}$ and $7.0 \%$ for Premis with 0.97 and 0.90 regression $\left(\mathrm{R}^{2}\right)$, respectively values obtained due to the nonlinear fitting of I \% data.

Destroying of cell wall and/or cytoplasm was probably the common mode of action due to $\mathrm{H}_{2} \mathrm{O}_{2}$ and Premis. This was in agreement with the findings of Abd El-Ghany and Tayel (2009). They suggested that Disorder and striking changes in the cell wall of hyphae, phialides and conidiophores were observed on Fusariumsolani, Rhizoctoniasolani and Peniciliumcitrinum. These alterations in the wall were not detected with the untreated hyphae. Disorganization of the cytoplasm was also recorded and vacuoles were completely disappeared in presence of the fungicide. Antifungal activity of $\mathrm{H}_{2} \mathrm{O}_{2}$ was also in full agreement with the data obtained by Leinaet al. (1998) who stated that spore germination in Pseudocercosporaabelmoschi and Pseudocercosporacruenta, pathogens of Hibiscus esculentus L. and Vignasinensis ssp. sesquipedalis (L.) van Eseltine, was significantly inhibited when incubated with different levels of hydrogen peroxide. They also found significant reduction in mycelial growth in both fungi at different levels of $\mathrm{H}_{2} \mathrm{O}_{2}$. Spore germination and mycelial growth were inhibited significantly at higher levels of peroxidase.

For garlic oil (Fig. 3), fitting linear was found to be the most acceptable $\left(0.98\right.$ regression $\left.\left(\mathrm{R}^{2}\right)\right)$, indicating that the tested dose was not limited yet

TABLE 3. Inhibitory effects of the tested control agents on the linear growth of the pathogenic fungus of maize late wilt disease under laboratory conditions.

\begin{tabular}{|c|c|c|c|c|c|c|}
\hline \multirow{2}{*}{ Treatment } & \multirow{2}{*}{$\begin{array}{c}\text { Concentration } \\
\%\end{array}$} & \multicolumn{4}{|c|}{ Linear growth $(\mathrm{Cm})$} & \multirow{2}{*}{$\begin{array}{l}\text { Inhibition } \\
(\%)\end{array}$} \\
\hline & & $\mathrm{R} 1$ & $\mathrm{R} 2$ & R3 & Mean & \\
\hline Algal filtrate & 100 & 0.0 & 0.0 & 0.0 & 0.00 & 100.00 \\
\hline \multirow[t]{2}{*}{ compost tea } & 10 & 4.3 & 4.8 & 4.8 & 4.63 & 23.63 \\
\hline & 3 & 0.7 & 0.6 & 0.6 & 0.63 & 89.56 \\
\hline \multirow[t]{3}{*}{$\mathrm{H}_{2} \mathrm{O}_{2}$} & 2 & 2.1 & 2.0 & 1.9 & 2.00 & 67.03 \\
\hline & 1 & 2.4 & 2.6 & 2.4 & 2.47 & 59.34 \\
\hline & 30 & 0.0 & 0.0 & 0.0 & 0.00 & 100.00 \\
\hline \multirow[t]{3}{*}{ Premis } & 20 & 2.1 & 2.4 & 2.1 & 2.20 & 63.74 \\
\hline & 10 & 2.9 & 2.8 & 2.6 & 2.77 & 54.40 \\
\hline & 6 & 0.1 & 0.0 & 0.2 & 0.10 & 98.35 \\
\hline \multirow[t]{2}{*}{ Garlic oil } & 3 & 2.4 & 3.1 & 2.6 & 2.70 & 55.49 \\
\hline & 1.5 & 5.1 & 5.1 & 4.8 & 5.00 & 17.58 \\
\hline $\begin{array}{l}\text { Barnyardgrass root } \\
\text { exudates }\end{array}$ & 100 & 0.1 & 0.2 & 0.2 & 0.17 & 97.25 \\
\hline Control & 0.0 & 6.2 & 5.9 & 6.1 & 6.07 & 0.00 \\
\hline
\end{tabular}

Env. Biodiv. Soil Security Vol.1 (2017) 


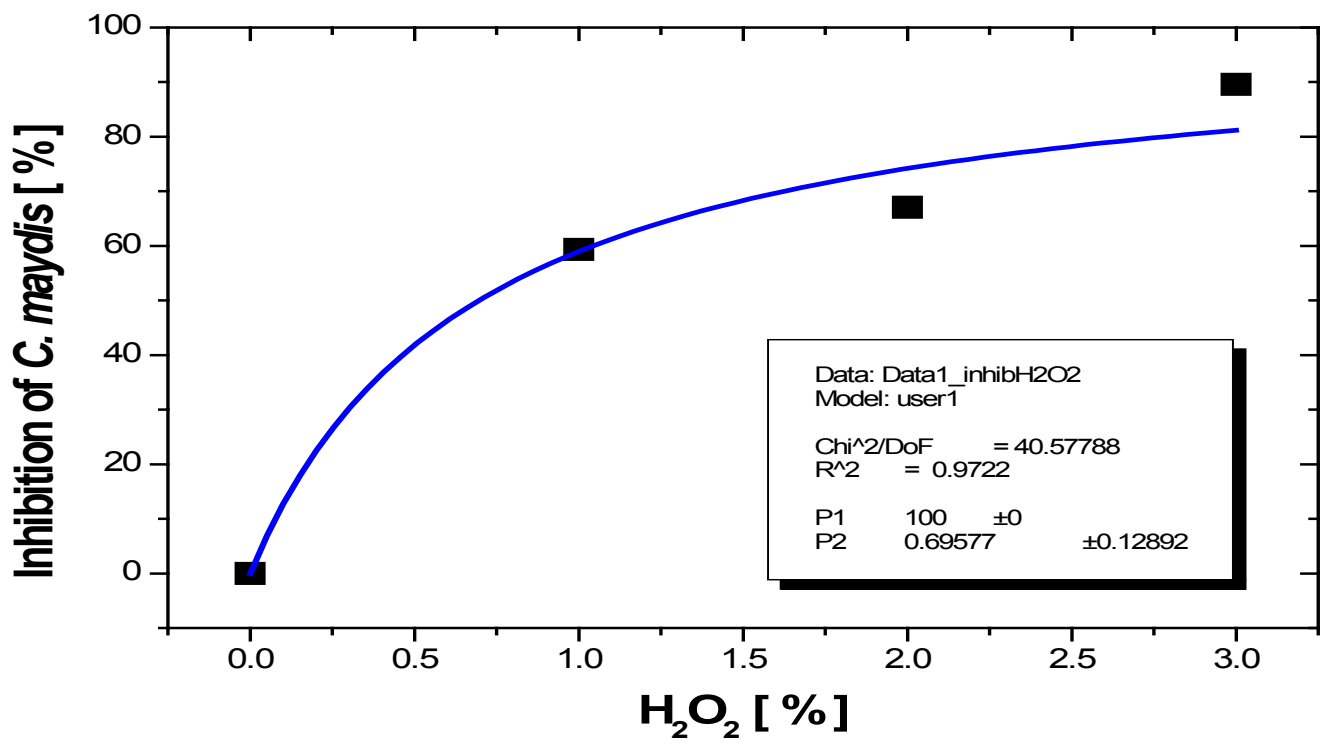

Fig. 1. Inhibitory effects of $\mathrm{H}_{2} \mathrm{O}_{2}$ against $\mathrm{C}$. maydis in relation to its concentrations. Symbol refers to the experimental data and line refers to fitted data with Monod's equation.

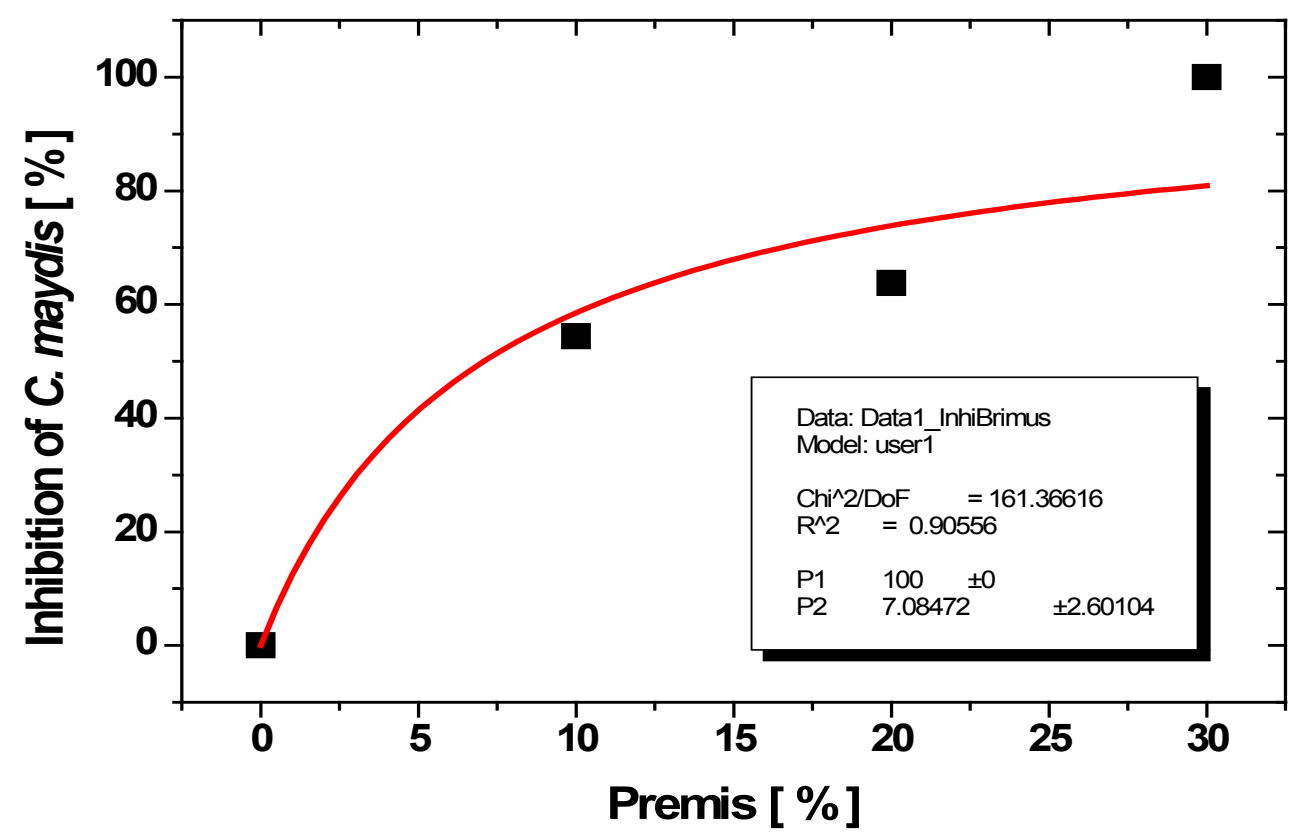

Fig. 2. Inhibitory effects of Premisagainst $C$. maydis in relation to its concentrations. Symbol refers to the experimental data and line refers to fitted data with Monod's equation. 
to the growth of the pathogenic fungus and more concentrations were needed to reach maximum inhibition. Here, $\mathrm{IC}_{50}$ value due to garlic oil reached $3.2 \%$ (Data not shown). Singh et al. (1997) found that growth of Fusariumoxysporium f. sp. ciceri and Sclerotiniasclerotiorum in liquid media incorporated with 5000 to 7000 ppm of garlic cloves juice was greatly reduced. Fungicidal activities of the ethanol extracts of Allium sativum, were in vitro achieved against Fusariumsolani, Rhizoctoniasolani and Macrophominaphaseolina (Dawaret al., 2008). They found also that ethanol extract of spices was more effective in the control of root rot pathogens as compared to aqueous extract.

Fitting data of $\mathrm{H}_{2} \mathrm{O}_{2}$, premis and garlic oil with the very good regression $\left(\mathrm{R}^{2}\right.$-values) were expressed by the simple kinetic parameters, which based on a limitation of growth rate by substrate concentrations. Similar explanation was confirmed by Barr and Aust (1994), who found that the metabolism of chemicals by bacteria and fungi involves mostly enzymatic conversions; pollutant degradation often follows Michaelis-Menten-type kinetics, which represented the enzymatic form of Monod kinetics (Monod, 1949). So, higher enzyme sensitivity of the pathogens toward $\mathrm{H}_{2} \mathrm{O}_{2}$, premis and garlic oil were compatible with greatest antagonistic effects. Nesci et al. (2003) explained that they may inhibit the functions of several enzymes by the oxidized compounds or/ and by more nonspecific interactions with the proteins. Based on regulation of the enzyme activity explained by Schlegel (1992), the cells may be containing sensitive system to adjust activity of these enzymes, in addition to regulation of its levels.

\section{Seed germination test}

Effect of the tested control agents on germination indexes and percentages of maize grains were tested during two successive seasons and data were presented in Table (4). Data of germination index and percentages showed varied readings with superiority of $3 \% \mathrm{H}_{2} \mathrm{O}_{2}$ treatment reached 1.52 and $54.73 \%$, respectively at 2015 season compared with control (1.43 and 49.87\%, respectively). Superiority of $3 \% \quad \mathrm{H}_{2} \mathrm{O}_{2}$ was delayed to the second level with 1.75 germination indexes and $55.40 \%$ germination percentages compared to 1.58 and $52.99 \%$, respectively for control at 2016 season. The highest corresponding values (1.88 and $63.07 \%)$ were recorded by the blue-green algal filtrates. Compost tea in the single form and in its combination with the algal filtrate were the following effective treatment with 1.67 and 1.66 indexes and 54.27 and 54.93 $\%$ percentages, respectively at the same season.

Although the tested agents have great antagonistic effects, data of the germination

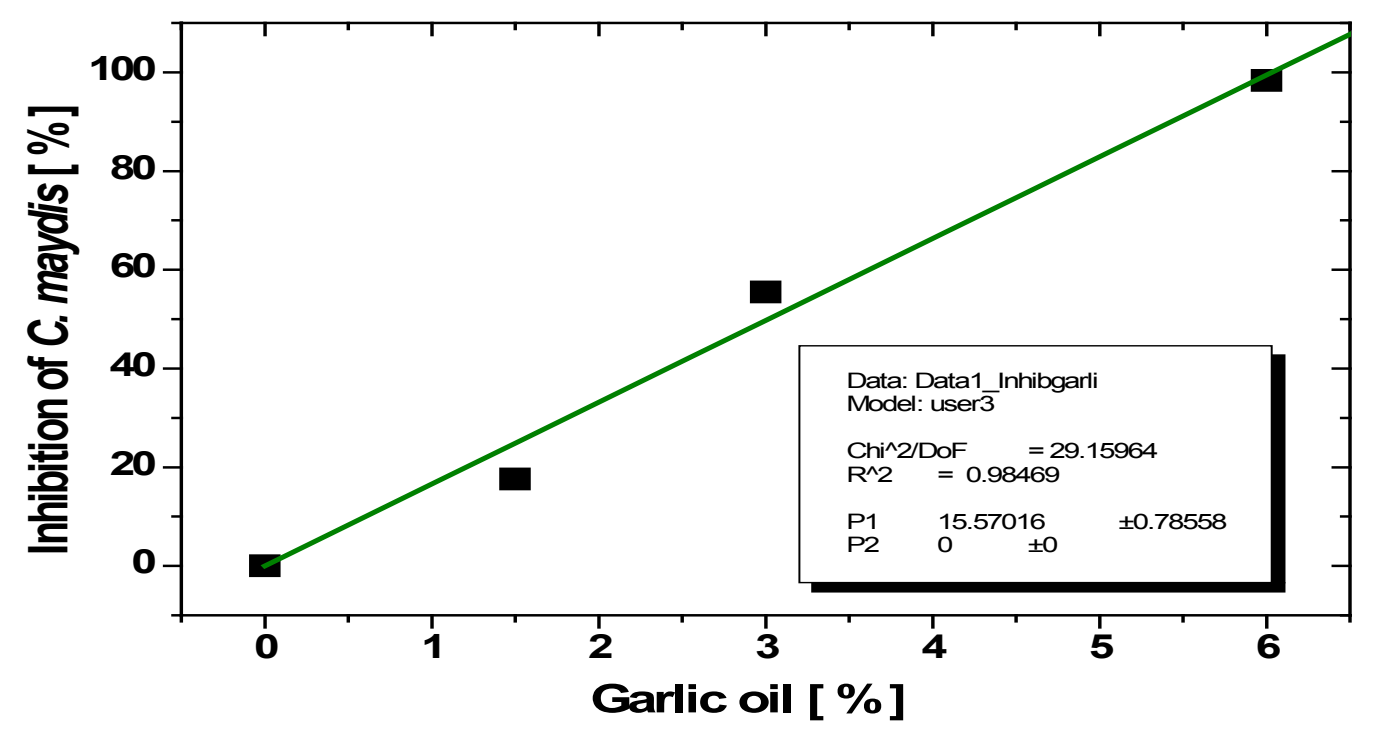

Fig. 3. Inhibitory effects of garlic oilagainst C. maydis in relation to its concentrations. Symbol refers to the experimental data and line refers to fitted data with Monod's equation.

Env. Biodiv. Soil Security Vol.1 (2017) 
test proved that their role played for promoting growth parameters doesn't appear clearly yet. Low germination of maize grains might be due to high available ammonium in polyethylene boxes (Ells et al., 1991).

\section{Disease assessment}

Effectiveness of the selected control agents was also evaluated against $C$. maydis under disease nursery conditions. During two successive growing seasons of 2015 and 2016, field experiments were carried out. Their efficacy towards late wilt disease expressions were represented by percentages of disease incidence, survival and disease reduction (Table 5). It is worthy to note that disease incidences of late wilt in control plants were nearly identical in both studied seasons (19.29 and $19.20 \%$ ), indicating equal severity of $C$. maydis inoculated the disease nursery in both seasons.
Data of disease incidence showed better efficacy of $30 \%$ Premis fungicide followed by $3 \% \mathrm{H}_{2} \mathrm{O}_{2}$ and dual treatment between compost tea and algal filtrate with $3.24,4.75$ and 5.10 $\%$ respectively during 2015 season, by them massive disease reductions reached 83.21, 75.37 and $73.54 \%$, respectively were done. It indicates that the defensive capacity of maize grains was increased due to suppressive effects of such treatments against the late wilt pathogenic fungus. Effectiveness of the $3 \% \mathrm{H}_{2} \mathrm{O}_{2}$ dose was extended to the 2016 season with $5.11 \%$ disease incidence and $73.39 \%$ disease reduction. Whereas, the $2 \% \mathrm{H}_{2} \mathrm{O}_{2}$ dose was the superior causing reduce of disease incidence to $4.42 \%$ or about 76.99 $\%$ disease reduction giving the highest value of $95.58 \%$ survival plants at 2016 season.

Moreover, significant efficacy for reducing disease incidence reached 7.06 causing $63.23 \%$

TABLE 4. Effect of the tested control agents on germination indexes and percentages of maize grains during 2015 and 2016 seasons in polyethylene box trials.

\begin{tabular}{|c|c|c|c|c|c|}
\hline \multirow{2}{*}{ Treatment } & \multirow{2}{*}{$\begin{array}{c}\text { Concentration } \\
\%\end{array}$} & \multicolumn{2}{|c|}{ Germination 2015} & \multicolumn{2}{|c|}{ Germination 2016} \\
\hline & & Index & $\%$ & Index & $\%$ \\
\hline Algal filtrate & 100 & 1.26 & $46.67 \mathrm{abc}$ & 1.88 & $63.07 \mathrm{a}$ \\
\hline compost tea & 10 & 1.28 & $46.60 \mathrm{abc}$ & 1.67 & $54.27 \mathrm{ab}$ \\
\hline \multirow[t]{2}{*}{ Compost tea + Algal filtrate } & $1: 1$ & 1.41 & $51.33 \mathrm{ab}$ & 1.66 & $54.93 \mathrm{ab}$ \\
\hline & 3 & 1.52 & $54.73 \mathrm{a}$ & 1.75 & $55.40 \mathrm{ab}$ \\
\hline \multirow[t]{3}{*}{$\mathrm{H}_{2} \mathrm{O}_{2}$} & 2 & 1.21 & $43.00 \mathrm{abcd}$ & 1.50 & $51.80 \mathrm{abc}$ \\
\hline & 1 & 1.31 & $46.33 \mathrm{abc}$ & 1.40 & $46.53 \mathrm{bcde}$ \\
\hline & 30 & 1.18 & $41.60 \mathrm{abcd}$ & 1.27 & $40.80 \mathrm{de}$ \\
\hline \multirow[t]{3}{*}{ Premis } & 20 & 1.39 & $48.87 \mathrm{abc}$ & 1.49 & $48.53 \mathrm{bcd}$ \\
\hline & 10 & 1.38 & $49.40 \mathrm{abc}$ & 1.58 & $53.20 \mathrm{abc}$ \\
\hline & 6 & 1.01 & $36.80 \mathrm{bcd}$ & 1.07 & $36.27 \mathrm{ef}$ \\
\hline \multirow[t]{2}{*}{ Garlic oil } & 3 & 0.93 & $33.00 \mathrm{~cd}$ & 0.87 & $28.73 \mathrm{fg}$ \\
\hline & 1.5 & 0.85 & $29.80 \mathrm{~d}$ & 0.81 & $26.53 \mathrm{~g}$ \\
\hline Barnyardgrass root exudates & 1 & 1.42 & $49.60 \mathrm{abc}$ & 1.26 & $41.33 \mathrm{cde}$ \\
\hline Barnyard cultivation & - & 1.39 & $48.40 \mathrm{abc}$ & 1.46 & $53.20 \mathrm{abc}$ \\
\hline Control & 0 & 1.43 & $49.87 \mathrm{abc}$ & 1.58 & $52.99 \mathrm{abc}$ \\
\hline
\end{tabular}

Averages in a column followed by a different letter are significantly different at 0.05 level after a Duncan`s multiple range test. 
TABLE 5. Effects of the tested control agents on rating of late wilt disease index parameters of maize plants in the disease nursery during 2015 and 2016 growing seasons

\begin{tabular}{|c|c|c|c|c|c|c|c|}
\hline \multirow{3}{*}{ Treatment } & \multirow{3}{*}{$\begin{array}{c}\text { Concentration } \\
\%\end{array}$} & \multicolumn{6}{|c|}{ Disease expressions ( \% ) } \\
\hline & & & 2015 & & & 2016 & \\
\hline & & $\begin{array}{c}\text { Disease } \\
\text { incidence }\end{array}$ & $\begin{array}{c}\text { Survival } \\
\text { plants }\end{array}$ & $\begin{array}{l}\text { Disease } \\
\text { reduction }\end{array}$ & $\begin{array}{c}\text { Disease } \\
\text { incidence }\end{array}$ & $\begin{array}{c}\text { Survival } \\
\text { plants }\end{array}$ & $\begin{array}{l}\text { Disease } \\
\text { reduction }\end{array}$ \\
\hline Algal filtrate & 100 & $8.75 \mathrm{bc}$ & 91.25 & 54.65 & $10.63 \mathrm{ab}$ & 89.37 & 44.63 \\
\hline compost tea & 10 & $12.26 \mathrm{~b}$ & 87.74 & 36.41 & $7.06 \mathrm{~b}$ & 92.94 & 63.23 \\
\hline $\begin{array}{l}\text { Compost tea }+ \\
\text { Algal filtrate }\end{array}$ & $1: 1$ & $5.10 \mathrm{c}$ & 94.90 & 73.54 & $11.65 \mathrm{ab}$ & 88.35 & 39.28 \\
\hline & 3 & $4.75 \mathrm{c}$ & 95.25 & 75.37 & $5.11 \mathrm{~b}$ & 94.89 & 73.39 \\
\hline $\mathrm{H}_{2} \mathrm{O}_{2}$ & 2 & $6.27 \mathrm{c}$ & 93.73 & 67.51 & $4.42 \mathrm{~b}$ & 95.58 & 76.99 \\
\hline & 1 & $7.41 \mathrm{bc}$ & 92.59 & 61.58 & $12.63 \mathrm{ab}$ & 87.37 & 34.21 \\
\hline & 30 & $3.24 \mathrm{c}$ & 96.76 & 83.21 & $7.96 \mathrm{~b}$ & 92.04 & 58.53 \\
\hline Premis & 20 & $6.20 \mathrm{c}$ & 93.80 & 67.86 & $11.10 \mathrm{ab}$ & 88.90 & 42.18 \\
\hline & 10 & $8.11 \mathrm{bc}$ & 91.89 & 57.93 & $9.41 \mathrm{~b}$ & 90.59 & 50.96 \\
\hline & 6 & $6.92 \mathrm{c}$ & 93.08 & 64.12 & $7.56 \mathrm{~b}$ & 92.44 & 60.61 \\
\hline Garlic oil & 3 & $8.55 \mathrm{bc}$ & 91.45 & 55.64 & $10.69 \mathrm{ab}$ & 89.31 & 44.29 \\
\hline & 1.5 & $8.36 \mathrm{bc}$ & 91.64 & 56.67 & $12.17 \mathrm{ab}$ & 87.83 & 36.57 \\
\hline $\begin{array}{l}\text { Barnyardgrass } \\
\text { root exudates }\end{array}$ & 1 & $6.43 \mathrm{c}$ & 93.57 & 66.67 & $7.12 \mathrm{~b}$ & 92.88 & 62.91 \\
\hline $\begin{array}{l}\text { Barnyard } \\
\text { cultivation }\end{array}$ & - & $9.02 \mathrm{bc}$ & 90.98 & 53.23 & $9.13 \mathrm{~b}$ & 90.87 & 52.44 \\
\hline Control & 0 & $19.29 \mathrm{a}$ & 80.71 & 0.00 & $19.20 \mathrm{a}$ & 80.81 & 0.00 \\
\hline
\end{tabular}

Averages in a column followed by a different letter are significantly different at 0.05 level after a Duncan`s multiple range test.

disease reductions and $92.94 \%$ survival percentage due to use compost tea during 2016 season. This was in agreement with Kone'et al. (2010), who attributed effect of compost teas to the physical and chemical properties of its nutrients. This may improve the nutritional status of plants, be directly toxic to the pathogen, and/ or induce systemic resistance to the pathogen. A hypothesis stated that compost tea seems to act as a bio-control of pathogens by favoring the growth of beneficial bacteria (Diánezet al., 2007). Therefore, compost tea considered one of the most promise bio-products recently responsible for developing different management programs as plant pest, disease and fertility, in addition to promote growth of the plants. Accordingly, antagonistic effect of compost tea was confirmed against Pythiumultimum, Rhizoctoniasolani, Phytophthoraspp, Fusariumoxysporum and Verticilliumdahliae (Noble and Coventry, 2005). Similarly of compost tea, Barnyard grass extract, $6 \%$ garlic oil and $30 \%$ premis were considered of the most effective control agents of late wilt disease at 2016 season, respectively. By yeast strain, role played for controlling late wilt disease, Env. Biodiv. Soil Security Vol.1 (2017) but with non-significant magnitudes. Grain Productivity

Due to their relative convergence, weight of both 10 ears and 1000 grains of both experimental seasons of maize plants were investigated. Concerning weights of 10 ears, Fig. (4) Indicated great enhancements due to use all treatments compared to control. As well as, data presented in Table (6) showed majority weights of the 1000 grain yield reached $0.461 \mathrm{Kg}$ due to use $1 \%$ $\mathrm{H}_{2} \mathrm{O}_{2}$ application during 2015 season compared to $0.357 \mathrm{Kg}$ for control. Whereas, the maximum weight of 1000 grains reached $0.471 \mathrm{Kg}$ was recorded by using $1.5 \%$ garlic oil compared to $0.408 \mathrm{Kg}$ for control during 2016 season. It was in the same trend indicated general improvements of the 1000 grains weights due to most tested agents during both seasons. Here, it is worthy to notice that the great suppressive efficiencies of both 2 and $3 \% \mathrm{H}_{2} \mathrm{O}_{2}$ doses did not reflex to enhance grain productivity, but reduction was resulted. It indicated toxicity of the plant tissues due to use higher doses of $\mathrm{H}_{2} \mathrm{O}_{2}$ leading to reduce their ability to form new grain primordia cells in 
maize ears. On contrary with findings of Shalaby et al. (2011), effect of compost tea for increasing weight of 1000 grains was less magnitude in the presented study.

\section{Biochemical analysis}

Due to their remarkable antagonistic efficiencies against $C$. maydis and yield enhancing role, chemical compositions of both blue-green algae and root exudates of barnyard grass was assessed. Bluegreen algae and root exudates of Echinochloagrusgalli (Barnyard grass) were assayed on Gas chromatography mass-spectrum (GC-MS) for making qualitative analysis. Results presented in Table (7) and Fig. (5) indicated that the major compounds extracted from the cultured blue-green algae were summarized from 19 to seven compounds. Malonic acid, 2,3-Butandiol, Hexestrol, 12-Crown4-ether and cis-Vaccenic acid were the most abundant compounds. Their peaks appeared at 3.69, 4.60, 5.08, 6.72 and 16.86 minutes of retention time, respectively. For absolute quantification, the amount of endogenous compound can be calculated from peak areas. Malonic acid and 12-Crown-4-ether have maximum peak areas (18.53 and $18.56 \%$ of peak area, respectively) and then highest concentrations between the compounds which extracted from the blue-green algae. The cis-Vaccenic acid ranks in the second order as concerns its concentration with $14.65 \%$ of peak area. The reminder 4 compounds recorded lower peak areas ranged between 7.87 to $5.18 \%$ ranked at the third order. There are 12 other compounds (Data not shown) recorded lowest concentrations in comparison with the other compounds, indicating weak antimicrobial activities.

The screening for antifungal compounds produced by cyanobacteria led us to discover new strains producing scytophycins and hassallidins. Antifungal compounds were detected from strains belonging to the Nostocales and Stigonematales orders, such as Anabaena, Fischerella, Nostoc and Scytonema (Guggeret al., 2002). The presented results were in agreement with Abed et al. (2009), who indicated that the antifungal compounds have been previously detected in cyanobacterial extracts, such as fischerellin A, hapalindole, hassallidin/balticidins, carazostatin, phytoalexin, tolytoxin, scytophycin, toyocamycin, tjipanazole, nostocyclamide, nostodione and nostofungicidine. Root exudates of Echinochloagrus-galli (Barnyard grass) were assayed and data were recorded in Table (8) and Fig. (6). It demonstrated that the major compounds were summarized from 39 to 14 compounds. Thymol and Vanillin were the first and second compounds appeared their peaks after 5.28 and 7.10 minutes of retention time from beginning, respectively. On the other hand, 3,5-di-t-ButylCatechol was the last one appeared its peak at 23.85 min. of retention time. For absolute quantification, the amount of endogenous compound can be calculated from peak areas. Nadolol has a maximum peak area (1000376571.2 of peak area) and then highest concentration between the compounds which extracted from the barnyard root exudates. Quinine ranks in the second order as concerns its concentration with 108216727.0 of peak area. $\alpha$ Methylionol and Phyllocladene ranked at the third order with 71330793.5 and 68315202.2 of peak areas. The other compounds included alcohols, acids, phenols, 2,6-dihydroxy benzoic acid or some metabolites represent antimicrobial agents, although they have lower concentrations.

The results indicated that the extracts of

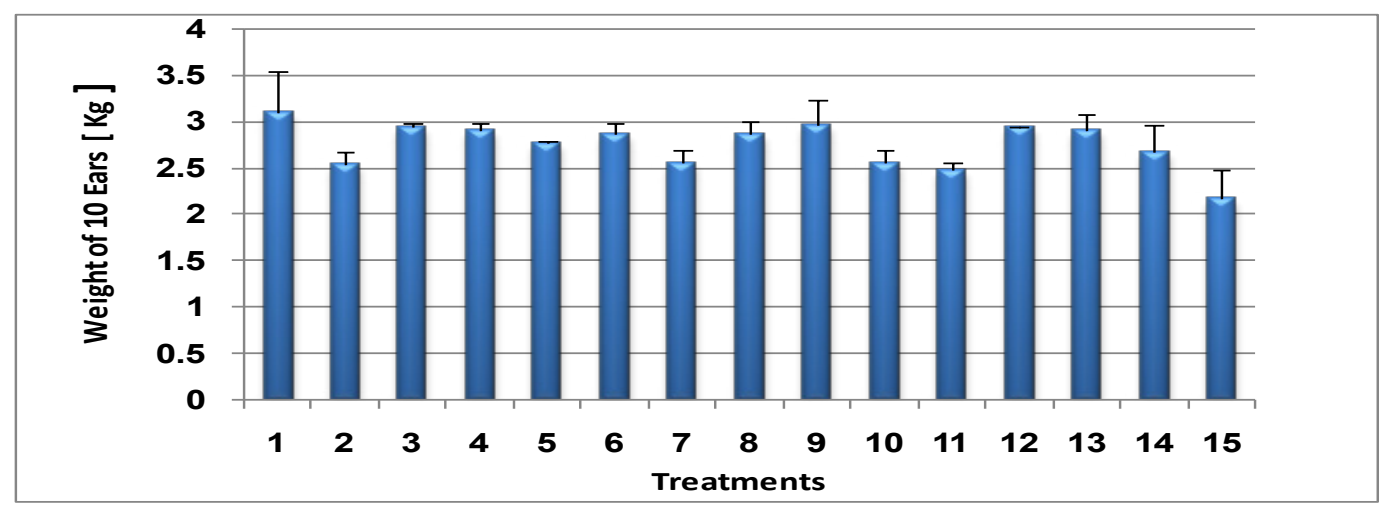

Fig. 4. Effect of the tested agents on the average weight of a 10 ears of maize plants in late wilt disease nursery and their significant power during the investigated seasons. Where: $1=$ Algal filtrate, $2=$ compost tea, $3=$ Compost tea + Algal filtrate, 4, 5, 6=3, 2, 1\% $\mathrm{H}_{2} \mathrm{O}_{2}, 7,8,9=30,20,10 \%$ premis, $10,11,12=6,3,1.5 \%$ garlic oil, 13= Barnyard grass extract, 14= Barnyard cultivation and 15= control.

Env. Biodiv. Soil Security Vol.1 (2017) 
TABLE 6. Effect of the tested control agents on weight of 1000 maize grains in the disease nursery during 2015 and 2016 growing seasons.

\begin{tabular}{lccc} 
Treatment & $\begin{array}{c}\text { Concentration } \\
\mathbf{\%}\end{array}$ & \multicolumn{2}{c}{ Weight of 1000 grains ( Kg ) } \\
Algal filtrate & 100 & $\mathbf{2 0 1 5}$ & $\mathbf{2 0 1 6}$ \\
compost tea & 10 & $0.389 \mathrm{bcd}$ & $0.416 \mathrm{abc}$ \\
Compost tea + Algal filtrate & $1: 1$ & $0.395 \mathrm{bc}$ & $0.449 \mathrm{ab}$ \\
& 3 & $0.386 \mathrm{bcd}$ & $0.451 \mathrm{ab}$ \\
$\mathrm{H}_{2} \mathrm{O}_{2}$ & 2 & $0.399 \mathrm{bc}$ & $0.382 \mathrm{bc}$ \\
& 1 & $0.376 \mathrm{~cd}$ & $0.365 \mathrm{c}$ \\
& 30 & $0.461 \mathrm{a}$ & $0.457 \mathrm{ab}$ \\
Premis & 20 & $0.385 \mathrm{bcd}$ & $0.419 \mathrm{abc}$ \\
& 10 & $0.397 \mathrm{bc}$ & $0.425 \mathrm{abc}$ \\
& 6 & $0.339 \mathrm{e}$ & $0.454 \mathrm{ab}$ \\
Garlic oil & 3 & $0.364 \mathrm{cde}$ & $0.428 \mathrm{abc}$ \\
& 1.5 & $0.368 \mathrm{cde}$ & $0.421 \mathrm{abc}$ \\
Barnyardgrass root exudates & 1 & $0.395 \mathrm{bc}$ & $0.470 \mathrm{a}$ \\
Barnyardgrass cultivation & & $0.417 \mathrm{~b}$ & $0.434 \mathrm{ab}$ \\
control & - & $0.402 \mathrm{bc}$ & $0.454 \mathrm{ab}$
\end{tabular}

Averages in a column followed by a different letter are significantly different at 0.05 level after a Duncan`s multiple range test.

TABLE 7. Chemical compositions of the blue-green algae extract analyzed by the laboratory of organic pollutants, ARC, Cairo, Egypt (Sample No. 3856). (7 from 19 compounds).

$\begin{array}{lc}\text { No. } & \text { RT }(\mathbf{m i n}) \\ 1 & 3.69 \\ 2 & 4.60 \\ 3 & 5.08 \\ 4 & 6.09 \\ 5 & 6.72 \\ 6 & 16.86 \\ 7 & 17.06\end{array}$

$\begin{array}{cc}\text { Name } & \text { Area sum \% } \\ \text { Malonic acid } & 18.53 \\ \text { 2,3-Butandiol } & 7.87 \\ \text { Hexestrol } & 7.70 \\ \text { Polyneuridinedioldiacetate } & 5.33 \\ \text { 12-Crown-4-ether } & 18.85 \\ \text { cis-Vaccenic acid } & 14.56 \\ \text { cis-11-Eicosenoic acid } & 5.18\end{array}$

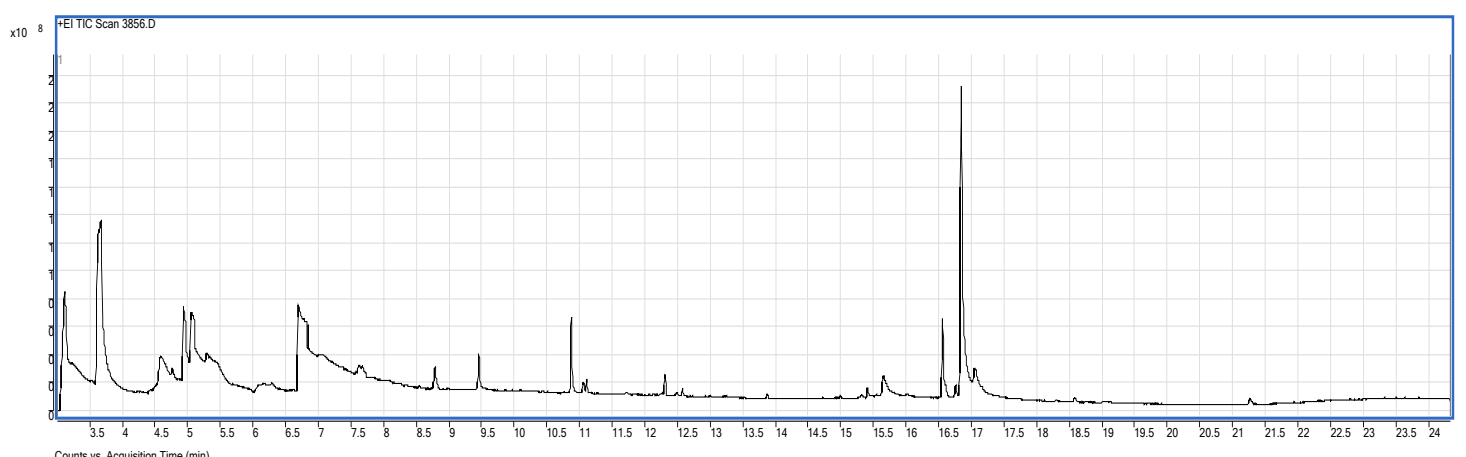

Fig. 5. Determination of the extracted compounds from the blue-green algaeon Gas chromatography massspectrum (GC-MS).

Env. Biodiv. Soil Security Vol.1 (2017) 
TABLE 8. Chemical compositions of the Echonocloa crus-gali (Barnyardgrass) root exudates analyzed by the laboratory of organic pollutants, ARC, Cairo, Egypt (Sample No. 1090). (14 from 39 compounds)

\begin{tabular}{|c|c|c|c|}
\hline No. & RT (min) & Name & Area \\
\hline 1 & 5.28 & Thymol & 10516841.2 \\
\hline 2 & 7.10 & Vanillin & 11233775.4 \\
\hline 3 & 10.22 & 3,3-Dinitro-4,4-dihydroxy-diphenylsulphone & 13658067.9 \\
\hline 4 & 12.25 & p-Cresol-2,2-methylenebis[6-tert-butyl] & 38158890.8 \\
\hline 5 & 15.33 & Cyanidin cation & 26467829.6 \\
\hline 6 & 16.01 & Argyrophilic acid methyl ester & 11605552.3 \\
\hline 7 & 16.55 & 3-Hydroxypyridine & 34817531.1 \\
\hline 8 & 16.93 & Phyllocladene & 68315202.2 \\
\hline 9 & 19.40 & Nadolol & 1000376571.2 \\
\hline 10 & 20.24 & Quinine & 108216727.0 \\
\hline 11 & 21.23 & 2,6-dihydroxy benzoic acid & 28999106.2 \\
\hline 12 & 21.87 & Phenol, 4-tert-butyl & 25909859.8 \\
\hline 13 & 22.02 & $\alpha$ - Methylionol & 71330793.5 \\
\hline 14 & 23.85 & 3,5-di-t-Butyl-Catechol & 20890823.3 \\
\hline
\end{tabular}

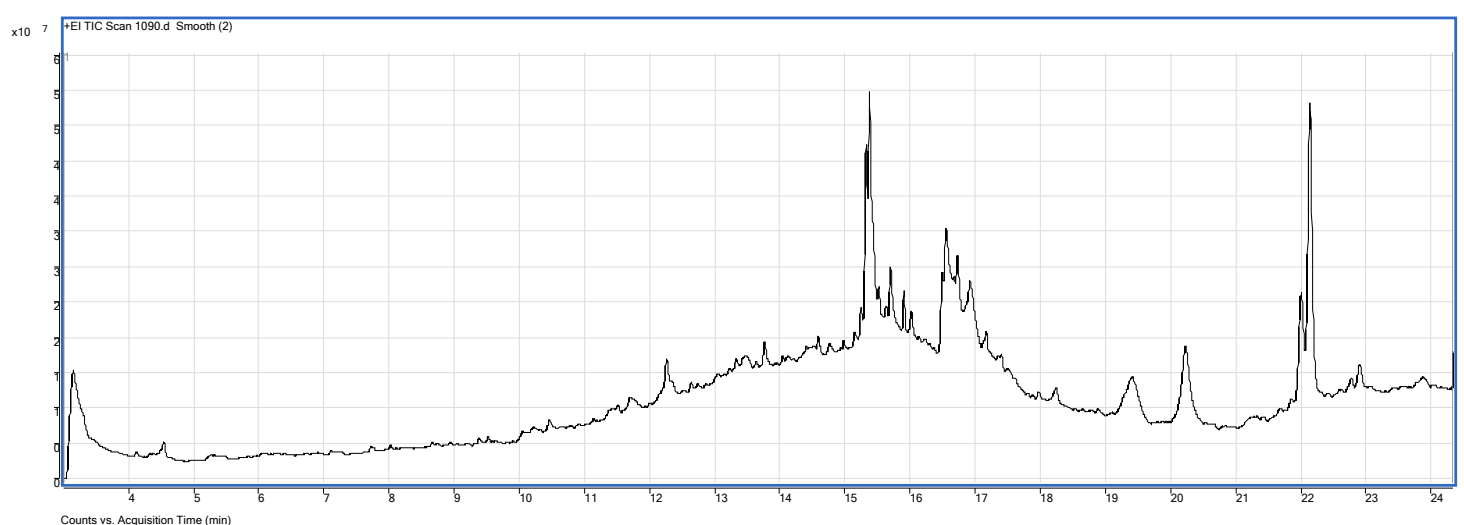

Fig. 6. Determination of the extracted compounds from the Echonocloa crus-gali (Barnyardgrass) root on Gas chromatography mass- spectrum (GC-MS).

barnyardgrass had the phytotoxic influence on maize plants. Varied antifungal degrees due to different areas of such barnyard grass root extracts were done. The degree of inhibition was largely dependent on barnyardgrass tissue types and the treated maize plants. These results specified that barnyardgrass release allelopathic substances such as 2,6-dihydroxy benzoic acid. These results were in full agreement with the finding of Li et al., (1992) and Yamamoto et al., (1999) who suggested that allelopathy of barnyardgrass against crops was correlated with the amounts of phenolic acids released specially phydroxybenzoicacid.

Weeds especially barnyardgrass can produce many kinds of secondary metabolites through its tissues. These metabolites in barnyardgrass root extracts possess multiple functions on the chemical interactions among organisms in the environment. Our results were in agreement with results of Xuan et al., (2006) who suggested that p-Hydroxybenzaldehyde, phydroxybenzen and p-hydroxybenzoicacid as major allelochemicals in barnyardgrass. They recommended that these compounds may be, at least, a key factor in barnyardgrassallelopathy on rice and other crops. The amount of nitrogen content is often equivalent by protein content in crop production. By using of allelopathy definition, it is obvious that allelochemicals could affect all phases of nitrogen biological fixation, mineralization and nitrification (Reigosaet al., 2006). So, applicability of such effective and environmentally safe tested agents for overcome, or at least reduces, the 
harmful effects of the chemical fungicides applied for controlling late welt disease and enhancement maize productivity was preferred to recommend as promising agents.

\section{References}

Abd El-Ghany, T. M. and A. Tayel (2009) Effecacy of certain agrochemicals application at field rates on soil fungi and their ultra-structures. Res. J. Agric. Biological Sci., 5 (2): 150-160.

Abdel-Raouf, Neveen and Nadia M. El-Shafey (2009) Harmful effects of endosulfan treatment on cyanobacterial distribution and some macromolecules of soybean plant, African $J$. Biotechnol., 8 (22): 6277-6281.

Abed, R.M.; Dobretsov, S. and Sudesh, K. (2009) Applications of cyanobacteria in biotechnology. $J$. Appl. Microbiol., 106, 1-12.

Abhay, R.; Krishna, R.M.M. and C. Ram (2007) Industrial commercial lignins: Sources, properties and applications. International Biodeterioration and Biodegradation, 59 (4), 292-296.

Allen, M. M. and R.Y. Stainer (1968) Growth and division of some unicellular blue-green algae. $J$. $G$. Microbiol., 51, P. 203.

Badawi, F. (2003).Studies on bio-organic fertilization of wheat under newly reclaimed soils. Ph.D Thesis, Fac. of Agric., Cairo Univ., Egypt.

Barr, D.P. and Aust, S.D. (1994) Pollutant degradation by white rot fungi. Source Rev. Environ. Contam. Toxicol., 138, 49-72.

Booth, C. (1977) Fusarium: Laboratory Guide To The Identification Of The Major Species, Commonwealth Mycological Institute, Kew, Surry, England.

Bowen, G.D. and A.D. Rovira (1999) The rhizosphere and its management to improve plant growth. $A d v$. Agron., 66, 1-102.

Brinton, W. (1995). The control of plant pathogenic fungi by use of compost teas. Biodynamics, 197, 12-15.

Cooper, A.J. (1973) Rapid cropturnaroundispossiblewith experimentalnutrientfilmtechnique. Grower,79,1048,1050,1052 .

Dawar, Shahnaz; Abbas, S.; Tariq, M. and Zaki, J. M. (2008) In vitro fungicidal activity of spices against root infecting fungi. Pakistan. University of Karachi, Karachi. J. Bot., 40 (1), 433-438.

Env. Biodiv. Soil Security Vol.1 (2017)
Diánez F.; Santos, M. and Tello, J.C. (2007) Suppressive effects of grape marc compost on phytopathogenicoomycetes. Archives of Phytopathology and Plant Protection, 40 (1), 1-18.

El-Bakery, Amal, M. (2010) Biological control of Cephalosporiummaydis the causal organism of late wilt disease on maize. M. Sc. Thesis Fac. Sci., Zagazig Univ. Egypt 108 pp.

Ells, J.E.; A. E. Mc Say and S. M. Workman (1991) Toxic effects of manure alfalfa and ammonium on emergence and growth of cucumber seedlings. Hort. Sci., 26, 380-383.

El-Shafey, H.A. and L.E. Claflin (1999) Late Wilt. Pages 43-44 In: Compendium of Corn Diseases, $3^{\text {rd }}$ ed. D. G. White, ed. The American Phytopathological Socitey. St. Paul, MN.

Ferreira, J. H. S.; F. N. Mathee and A. C. Thomas (1991). Biological Control of Eutyptalota on grapevine by an antagonistic strain of Bacillus subtilis. Phytopathology, 81, 283-287.

Ghobrial, W. N.; Ahlam A. Mehesen; Jehan M. Abass; M. E. Shalaby and A. F. Omar (2009) Potential impacts of rhizobium and compost tea enhanced with rhizobacteria for enhancing protection of faba bean against broad bean mottle virus (BBMV). $J$. Agric. Res. Kafrelsheikh Uni., 35 (1), 20-38.

Gomez, K.A. and A.A. Gomez (1984) Statistical Procedure For Agricultural Research. 2 nd (ed.), John Wily \& Sons, New York.

Gugger, M.; Lyra, C.; Henriksen, P.; Couté, A.; Humbert, J.F. and Sivonen, K. (2002) Phylogenetic comparison of the cyanobacterial genera Anabaena and Aphanizomenon. Int. J. Syst. Evol. Microbiol. 2002, 52, 1867-1880. Mar. Drugs 2015, 132139

International Allelopathy Society (1993) The first world congress of allelopathy. Cadiz, Spain

Kaasalainen, U.; Fewer, D.P.; Jokela, J.; Wahlsten, M.; Sivonen, K. and Rikkinen, J. (2012) Cyanobacteria produce a high variety of hepatotoxic peptides in lichen symbiosis. Proc. Natl. Acad. Sci. USA, 109, 5886-5891.

Koné S. B.; A. Dionne; R. J. Tweddell; H. Antoun and T.J. Avis (2010) Suppressive effect of non-aerated compost teas on foliar fungal pathogens of tomato. Biological Control, 52, 167-173.

Leina Mary Joseph; Tan Teck Koon and Wong Sek Man (1998) Antifungal effects of hydrogen peroxide and peroxidase on spore germination and mycelial growth of Pseudocercospora species. Canadian Journal of Botany, 1998, 76 (12), 2119-2124. 
Li,H.H.; Urashima M.;Amamo M; Lajide L.; Nishimura, H.; Koji, H. and Mizutani J. (1992). Allelopathy of barnyardgrass (Echinochloacrusgalli L. Beauvvar curs-galli). Weed Res. Japan, 37, 146-152.

Monod, J. (1949). The growth of bacterial cultures. Ann. Rev. Microbiol., 3: 371-394.

Nesci, A.; Rodriguez, M. and Etcheverry, M. (2003) Control of Aspergillus growth and aflatoxin production using antioxidants at different conditions of water activity and pH. J. Appl. Microbiol., 95: 279-287.

Noble, R. and E. Coventry (2005) Suppression of soilborne plant diseases with composts: A review. Biocontrol Science and Technology, 15 (1), 3-20.

Reigosa, M.J.; Pedrol, N.and L. Gonzalez (2006) Allelopathy: A Physiological Process With Ecological Implications 19, 299-330

Rohrlack, T.; Christiansen, G. and Kurmayer, R. (2013) Putative antiparasite defensive system involving ribosomal and nonribosomaloligopeptides in cyanobacteria of the genus Planktothrix. Appl. Environ. Microbiol., 79, 2642-2647.

Samra, A.S., Sabet, K.A. and Hingorani, M.K. (1962) A new wilt disease of maize in Egypt. Plant Dis. Rep., 46: 481-483.

Scheurell, S. and W. Mahafee. (2002) Compost tea: Principles and prospects for plant disease control. Compost Science and Utilization, 10 (4), 313-338.

Schlegel, H.G. (1992) Allgemeine Mikrobiologie. $7^{\text {th }}$ edition. George ThiemeVerlag, Stuttgart, Germany.

Shalaby, M.E.; El-Gremi, Sh. M.; El-Kady, E. M. and El-Emary, Sh. A. (2015).Microbial and fungicidal antagonism of Fusariumoxysporum f. sp. beta for controlling wilting disease of sugar beet plants. Egy. J. Plant Pro. Res., 3 (1), 29-52.

Shalaby, M. E.; S. M. El-Moghazy; E. A. Abdelrasoul and Ahlam A. Mehesen (2011). Effect of some plant-growth promoters in controlling late wilt disease and enhancing nutritive value of maize plants. Egypt. J. of Appl. Sci., 26 (11), 369-385.

Shalaby, M. E.; S. M. El-Moghazy and Ahlam A. Mehesen (2009) Biological control of maize late wilt disease caused by Cephalosporiummaydis. $J$. Agric. Res. Kafrelsheikh Uni., 35 (1), 1-19.

Singh, R. S.; Daljeet-Singh and H. V. Singh (1997) Effect of fungal antagonists on the growth of chickpea plants and wilt caused by Fusariumoxysporium $f$. sp.ciceri. Plant Disease Research, 12 (2), 103-107.
Sønstebø, J. H. and Rohrlack, T. (2011) Possible implications of chytrid parasitism for population subdivision in freshwater cyanobacteria of the genus Planktothrix. Appl. Environ. Microbiol., 77, 1344-1351.

Tang, C. S. and C. C. Young (1982) Collection and identification of allelopathic compounds from undisturbed root system of Bigaltalimpograss (Hemaryhriaaltissima). Plant Physi., 69, 155-160.

Vestola, J.; Shishido, T.K.; Jokela, J.; Fewer, D.P.; Aitio, O.; Permi, P.; Wahlsten, M.; Wang, H.; Rouhiainen, L. and Sivonen, K. (2014) Hassallidins, antifungal glycolipopeptides, are widespread among cyanobacteria and are the end-product of a nonribosomal pathway. Proc. Natl. Acad. Sci. USA., 111, 1909-1917.

Vidaver-Anne, K.; Mathys-Mary, L.; Thomas, E. and Schuster, M.L. (1972) Bacteriocins of the phytopathogens Pseudomonas syringe, P. glycinea and P. phaseolicola. Canadian J. Microbiology, 18 (6): 705-713.

Walker-Simnous, M. K. and J. Sesing (1990) Temperature effects on embryonic absecisic acid levels during development of wheat grain dormancy. J. of Plant Growth Regulators, 9, 51-56.

Whipps, J. M. (2001) Microbial interactions and biocontrol in the rhizosphere. Journal of Experimental Botany, 52, 487-511.

Whitton, B. A. and Potts, M. (2000) Introduction to cyanobacteria. In The Ecology of Cyanobacteria. Their Diversity in Time and Space; Whitton, B.A., Potts, M., Eds.; Kluwer Academic: Dodrecht, The Netherlands; pp. 61-120.

Xuan, T. D.; Chung, I. M.; Khanh, T. D. and Tawata, S. (2006) Identification of phytotoxic substances from early growth of barnyardgrass (Echinochloa crusgalli) root exudates. J Chem Ecol 32, 895-906.

Yamamoto, T.; Tomita, K. Y.; Kosemura, S.; Yakamura, S.; Yamada, K. and Hasegawa, K. (1999) Allelopathic substance exuded from a serious weed, germinating barnyard grass (Echinochloacrusgalli) root. J. Plant Growth Regul., 18, 65-67.

Zoschke, A. (1990) Yield losses in tropical rice as inuenced by the composition of weed ora and the timing of its elimination. In: Pest Management in Rice (eds BT GRAYSON, MB GREEN \& LG COPPING) 300-313. Elsevier Applied Science, New York, USA

(Received 16/10/2017; accepted 20/11/2017) 